\title{
НАСИЛЬСТВО В СІМ'Ї: КРИМІНАЛІСТИЧНА ХАРАКТЕРИСТИКА ТА МЕТОДИ БОРОТЬБИ
}

Комісарчук Р. В., Островська А. Ю.

\begin{abstract}
Метою статmі є висвітлення однієї з найбільш важливих проблем сьогодення - домашнього насильства. Значний сегмент у загальній насильницькій злочинності належить насильству, учиненому в сім'ї. Даний вид злочинності є досить небезпечним соціальним явищем, бо передусім обмежує конституційні права і свободи найменш захищеної категорії громадян - жінок, дітей і осіб похилого віку. Тому проблема убезпечення громадян від сімейного насильства потребує невідкладного вирішення цілого комплексу проблем - правових, організаційних, економічних, медичних тощо, а в підсумку - криміналістичних.
\end{abstract}

Злочинність, сімейні біди, пияцтво переплетені у вирі соціального життя як складні негативні процеси; немає жодних сумнівів у тому, що оздоровлення суспільства залежить від зваженого й науково обгрунтованого підходу до вирішення всіх без винятку проблем, що становлять зазначений феномен. Водночас за активного дослідження багатьох сучасних видів злочинності практично не приділяється увага вивченню й аналізу кримінального явища, головними дійовими особами якого є члени сім'ї. Як наслідок, спостерігається ускладнення багатьох сегментів соціального буття, зокрема й таких, що не пов'язані безпосередньо із зазначеним явищем. Тому цілком зрозуміло, чому саме сьогодні досліджувана проблема перебуває в центрі уваги засобів масової інформації, законодавчих та правоохоронних органів. Якщо раніше насильницька злочинність була атрибутом лише маргінальних верств населення, то нині значно збільшилася кількість протиправних діянь, що вчиняються в цілком благополучних сім'ях. Водночас феномен насильницьких злочинів, що вчиняються в сім'ї, опосередковано негативно впливає на майже всі сфери соціальних відносин. Тому означена складова частина насильницьких злочинів потребує дослідження через їхні детермінанти, що надасть можливість означити криміналістичну характеристику даного виду злочинів; навести класифікацію насильницьких дій у родині; описати методи виявлення й передумови для формування концепції боротьби з домашнім насильством на рівні взаємодії держави та суспільства.

Ключові слова: домашнє насильство, насильницькі злочини, фізичне насильство, психологічне насильство, насильство в сім'ї.
Komisarchuk R. V., Ostrovska A. Yu. Domestic violence: forensic characteristics and methods of struggle

The purpose of the article is to highlight one of the most important problems of our time - domestic violence. Domestic violence is the most significant segment of total violent crime. This type of crime is a rather dangerous social phenomenon, since it primarily restricts the constitutional rights and freedoms of the least protected category of citizens - women, children and the elderly. Therefore, the problem of citizens' safety from domestic violence requires urgent solutions to a whole range of problems - legal, organizational, economic, medical, etc., and as a result - criminalistic.

Crime, family troubles, drunkenness - as complex negative processes in the maelstrom of social life are intertwined; and there is no doubt that the recovery of society depends on a balanced and scientifically based approach to solving all the problems of this phenomenon without exception. At the same time, with a fairly active study of many modern types of crime, almost no attention is paid to the study and analysis of the criminal phenomenon, the main characters of which are family members. As a result, in relation to this, there is a complication of many segments of social existence, including those that are not directly related to this phenomenon.

Therefore, it is quite clear why today this problem is in the center of attention of mass media, legislative and law enforcement bodies. If earlier violent crime was an attribute of only marginal segments of the population, now the number of illegal acts committed in well-off families has significantly increased. At the same time, violent crimes committed in the family has indirectly negatively affect on almost all spheres of social relations without exception. Therefore, this component of violent crimes needs to be studied through their determinants, which will provide an opportunity to determine the forensic characteristics of this type of crime; provide a classification of domestic violence; describe the methods of detection and identify the prerequisites for the formation of the concept of combating domestic violence at the level of interaction between the state and society.

Key words: domestic violence, violent crimes, psychological violence, mental violence, violence in family.

(c) Комісарчук Р. В., Островська А. Ю., 2020 
Постановка проблеми та іï актуальність. Розвиток негативних процесів у складний для країни період загострив дестабілізаційні явища, що негативно відбилося на сімейних відносинах. Сучасна українська сім'я відчуває кризу. Сварки між родичами все частіше набувають злочинного характеру: від побоїв до вбивств. Особливо нині, у період пандемії, домашнє насилля можна назвати «пандемією всередині пандемії». Однак карантин не створює проблему в сім'ї, він iї тільки показує. Насильник - завжди насильник, незалежно від того, проявляє він себе до того чи ні. Проблему легше приховати, коли розійшлися в різні кінці міста на роботу чи для іншої діяльності. Але в період ізоляції ситуація в сім'ї загострюється і призводить до домашнього насилля.

Тому актуальність роботи та соціальна значущість даної проблематики виявляються в тому, щоби вчасно розпізнати домашнє насильство, його ознаки, форми, запобігти насильницьким діям чи зупинити їх. Для цього потрібно розробити відповідні методи виявлення домашнього насильства та сформувати відповідні передумови для концепції протидії домашньому насильству та профілактики його з боку держави та суспільства.

Аналіз останніх досліджень і публікацій. Теоретичні дослідження в цьому напрямі проводили вчені з різних галузей права, психології та соціології. Серед них П.О. Власов, А.Д. Дашиєва, І.О. Ієрусалимов, Ю.В. Лисюк, В.В. Нестерчук, В.В Топчій та інші.

Метою статті $\epsilon$ визначення окремих елементів криміналістичної характеристики насильницьких злочинів у сім'ї, з відповідним розкриттям їхніх детермінантів та методів боротьби.

Виклад основного матеріалу. Згідно з п. 3 ч. 1 ст. 1 Закону України «Про запобігання та протидію домашньому насильству», домашнє насильство - діяння (дії або бездіяльність) фізичного, сексуального, психологічного або економічного насильства, що вчиняються в сім'ї чи в межах місця проживання або між родичами, або між колишнім чи теперішнім подружжям, або між іншими особами, які спільно проживають (проживали) однією сім'єю, але не перебувають (не перебували) у родинних відносинах чи у шлюбі між собою, незалежно від того, чи проживає (проживала) особа, яка вчинила домашнє насильство, у тому самому місці, що й постраждала особа, а також погрози вчинення таких діянь [2].

Варто зауважити, якщо раніше під домашнім насильством розумілись інциденти, що виникли між подружжям, то відтепер розширюється коло осіб. Зокрема, це колишній чоловік або дружина, взято до уваги також громадянські шлюби, прийомних батьків, осіб, які спільно проживають чи проживали в одній родині, рідних братів, сестер, опікунів та інших родичів, а також осіб, які знайшли притулок в інших осіб і потрапили в матеріальну, психологічну або іншу залежність від них унаслідок нездатності забезпечити догляд за собою, самостійно захищати свої права через неповноліття.

У процесі розгляду проблематики домашнього насильства варто взяти до уваги чинники, які породжують таке насильницьке ставлення. До них ми відносимо такі, як: недоліки сімейного виховання, втрата розуміння поняття «культ сім'ї; деградація вітчизняної культури внаслідок розмивання меж моральності, морального й аморального; негативна роль засобів масової інформації, адже ймовірність піддатися насильству істотно підвищилася з появою відеоігор, відеофільмів, інтернету; політична й економічна кризи, криза ідеології та моральності, виникнення жорстокості в суспільстві; втрата авторитету батьків, закону, влади; неефективне функціонування правоохоронної системи [6, с. 144].

Оскільки сім'я - невід'ємний елемент домашнього насильства та пов'язаних із ним злочинних діянь, варто зазначити, що вона $\mathrm{i} \epsilon$ осередком формування чинників насильства, особливо неблагополучна сім'я.

Насильство в підлітковому та зрілому віці $\epsilon$ наслідком конфліктів між батьками та між батьками й дітьми протягом перших років життя дитини. Так, підхід до виховання дитини ремінцем також уважається насильством. Варто згадати і про те, що високому ступеню ризику домашнього насилля піддається сім'я, де один чи обоє батьків не $є$ біологічними. Також більше піддаються ризику насильства діти, які ростуть у родині з одним із батьків. Як приклад можна навести сім'ї, у яких один чи двоє батьків мають кримінальне минуле. Низький соціально-економічний статус родини також має прямий зв'язок із насильством у майбутньому [9, с. 38].

Ще однією причиною домашнього насилля може виступати прагнення до влади в родині. Під сімейною владою прийнято розуміти здатність одного члена сім'ї змінювати поведінку або впливати на поведінку інших членів за допомогою тиску на членів сім'ї, примушування їх виконувати певні дії. Варто зазначити, що поведінка владної людини багато в чому характеризується проявами агресивності, яка виражається у ворожому ставленні до проявів підлеглої людини. 
Соціолог К. Сафіліос-Ротшильд виділяє вісім типів влади, що виявляються в сім'ях, як-от: легітимна влада, влада пана, влада ресурсів, експертна влада, влада впливу, емоційна влада, влада управління конфліктом, моральна влада [5, c. 32].

Також під час характеризування домашнього насильства як виду злочину варто надати його криміналістичну характеристику.

Відповідно до ст. 126-1 Кримінального кодексу України, домашнім насильством визначається умисне систематичне вчинення фізичного, психологічного або економічного насильства щодо подружжя чи колишнього подружжя або іншої особи, з якою винний перебуває (перебував) у сімейних або близьких відносинах, що призводить до фізичних або психологічних страждань, розладів здоров'я, втрати працездатності, емоційної залежності або погіршення якості життя потерпілої особи [1].

Пропонуємо більш детально розглянути форми домашнього насилля.

Одним із найпоширеніших видів насильства $\epsilon$ фізичне насильство, яке може проявлятися в нанесенні ударів, побоїв, поранень, а також у впливі на зовнішній покрив тіла людини шляхом застосування фізичної сили, зброї або інших предметів, рідин, а також у впливі на внутрішні органи людини без пошкодження зовнішніх тканин, обмеження реалізації фізичних потреб (їза та сон), обмеження свободи пересування, відмови в допомозі в разі хвороби або травми. Крайньою формою фізичного насильства $€$ тортури, завдання тяжкої шкоди здоров'ю, нанесення травм, несумісних із життям [3, с. 76].

Окремим видом фізичного насильства $\epsilon$ сексуальне насильство, яке вчиняється у формі зґвалтування, тобто статевих зносин із застосуванням фізичного насильства або із використанням безпорадного стану потерпілої особи, насильницького задоволення статевої пристрасті неприродним способом, які здатні задовольнити статеву пристрасть особи. До них відносимо лесбіянство, мужолозтво, аногенітальний контакт, орогенітальний контакт, сурогатні форми статевих зносин, які імітують природний статевий акт, садистські дії сексуального характеру, сексуальний мазохізм [10, с. 366$]$.

Проявами психологічного насильства визнають такі дії: ігнорування почуттів особи; образу переконань, що мають цінність для особи, їі віросповідання, національної, расової приналежності або походження; соціального статусу; пересліду- вання, залякування; примус; приниження особистості; постійну критику та насмішки тощо [8].

Психологічне насильство часто спричиняє депресії, нервові розлади, загострення хронічних захворювань, навіть призводить до самогубства. Психологічне насильство в сім'ї найчастіше супроводжує і всі інші види насильства.

Економічне насильство проявляється в таких ознаках, як: позбавлення ресурсів для належного фізичного та психологічного добробуту; підзвітність за витрачені гроші та / або відбирання всіх зароблених грошей; заборона на працю члену сім'ї, незважаючи на його бажання та працездатність; інші ознаки. Одним із найбільш поширених проявів економічного насильства в Україні $\epsilon$ вигнання з дому (квартири), що здебільшого застосовується до жінок та дітей [8].

Оскільки характеризуємо домашнє насильство як вид злочину, варто вказати основні його ознаки: 1) об'єктом посягання виступають захищені кримінальним законом суспільні відносини із забезпечення найцінніших фізичних благ - життя і здоров'я особи; 2) насильницькі дії здійснюються із прямим або непрямим умислом; 3) наслідки таких дій виникають у разі застосування фізичного або психічного насильства у вигляді позбавлення життя, завдання болю, образи або фізичного сорому; 4) метою застосування насильства $\epsilon$ бажання підпорядкувати собі інших членів сім'ї, покарати їх за «непослух», досягнення певної цілі або захист від застосовуваного насильства щодо себе або інших членів сім'ї.

Окрім загальних ознак насильства, насильство в сім'ї має деякі особливості: суб'єктами $\epsilon$ рідні люди - члени сім'ї; необхідність продовжувати спілкування насильника із жертвою, зберігати й підтримувати систему міжособистісних взаємин [12, с. 183]; системність і тривалість; висока латентність; поєднання різних видів насильства [7, с. 32].

Портрет злочинця. Найчастіше насильницькі дії в сім'ї вчиняються особами середнього віку. Чому саме так? По-перше, саме в цьому віці вже складаються сімейні відносини й народжуються діти; по-друге, фізичний стан ще не обтяжений певними серйозними хворобами, а це означає хорошу фізичну форму; по-третє, саме в цьому віці люди частіше стикаються зі стресовими ситуаціями в будь-якій сфері, наслідками яких стають агресивність, конфліктність тощо. Наявність вищої освіти в таких осіб не $\epsilon$ гарантією позитивного ставлення до членів своєї сім'ї або близьких родичів [14, с. 87$]$. 
Особа потерпілого. Потерпілим від домашнього насильства може бути подружжя чи колишнє подружжя, або інша особа, з якою винний перебуває (перебував) у сімейних або близьких стосунках.

Обстановка вчинення злочину. Більшість осіб мали постійне місце проживання, де вчиняли домашнє насильство стосовно подружжя, колишнього подружжя, осіб, з якими перебували в сімейних або близьких стосунках.

Стосовно знаряддя вчинення злочину дослідник О.В. Радзевілова зазначає, що під час імпульсивного вибору знаряддя правопорушення зазвичай трапляється «те, що було найближче до рук» [13, с. 146]. Найчастіше таким засобом виявляється кухонний ніж або інші колючо-ріжучі предмети побутового призначення.

Спосіб учинення злочину. Злочини, пов'язані 3 домашнім насильством, здебільшого спонтанні, тобто вчиняються без попередньої підготовки. Умисел у злочинця виникає раптово, наприклад, на тлі сварки або нездатності врегулювання конфліктної ситуації. Проте у виняткових випадках скоєнню таких злочинів передує відповідна підготовка.

3 огляду на все вищезазначене, базова методика розслідування насильницьких злочинів у сім'ї має передбачати вироблення теоретичних основ криміналістичної характеристики даних злочинів. I першим етапом такого розроблення, уважаємо, має бути їх криміналістична класифікація.

За ознакою об'єкта насильницького злочину в сім'ї виділяють такі види насильства: 1) фізичне насильство - виражається в нанесенні ударів, побоїв, поранень та в іншому впливі на зовнішній покров тіла людини за допомогою застосування фізичної сили, холодної та вогнепальної зброї або інших предметів, рідин, сипучих речовин тощо; 2) сексуальне насильство - це замах на статеву недоторканність людини, інші дії, що порушують ii; 3) загроза насильства - будь-яка загроза завдання побоїв та інших ушкоджень дружині, дітям, іншим членам сім'ї, домашнім тваринам або собі; 4) психічне насильство - насильство, що завдає образи, породжує гнів, страх, психологічний занепад й емоційну нерішучість у власній значущості або нездатність захистити себе від фізичного, сексуального або подальшого психічного насильства; 5) нехтування обов'язками щодо дитини - невиконання обов'язків щодо забезпечення належною мірою [3, с. 75].

За такою ознакою, як структура способу злочину, насильницькі злочини в сім'ї можуть поділя- тися на повноструктурні, коли наявні підготовка, учинення та приховання злочину, та на неповноструктурні, які скоєні без підготовки та приховування. Найчастіше в разі скоєння насильницьких злочинів у сім'ї відсутній етап підготовки до даного злочину, тобто злочини відбуваються спонтанно, унаслідок розвитку конфліктної ситуації в сім'ї.

Особа потерпілого. Класифікацію ознак потерпілого можна виокремити за такою підставою, як поведінка до вчинення насильницького злочину в сім'ї - як агресивна, так і пасивна, щодо інших членів сім'ї. Агресивна поведінка виявляється в активному опорі кривднику. Пасивна поведінка у сім'ї потерпілий не дає відсічі насильницьким діям злочинця. Наприклад, сім'я протягом тривалого часу терпить образи, приниження, знущання, погрози, побої одного з їі членів і не звертається по захист у компетентні органи. Тим самим створюється, зберігається й загострюється обстановка, що сприяє скоєнню злочину.

Також варто вказати на таку ознаку, як поведінка після вчинення злочину. Вона проявляється у формі активного захисту своїх прав під час звернення до правоохоронних органів та у твердій позиції у процесі розслідування. Форма пасивної поведінки виявляється, наприклад, у разі замовчування про скоєний злочин, коли не звертаються у правоохоронні органи.

В переважній своїй частині насильницькі злочини в сім'ї відносять до категорії так званих латентних злочинів, тобто це скоєні злочини, які були приховані злочинцями або про які не було повідомлено потерпілими, свідками або іншими особами ні в один компетентний орган кримінальної юстиції [11, с. 13]. Тому для вчасного виявлення домашнього насильства та запобігання тяжким наслідкам насильства варто вміти виявляти ознаки та вчасно повідомляти до відповідних органів: дільничного інспектора поліції, кримінальної поліції у справах дітей, центру соціальних служб для сім'ї, дітей та молоді, управління сім'ї та молоді районної, міської чи обласної держадміністрацій, громадських організацій, які надають допомогу постраждалим від насильства, та до центрів із надання безоплатної правової допомоги. Велику роль для виявлення насильства в родині могли б відігравати освітні установи, оскільки за перших ознак погіршення стану дитини, іï неуспішності й занедбаному вигляді класні керівники, педагоги могли б своєчасно сигналізувати про ситуацію до органів поліції [4, с. 172]. 
Медичні працівники також можуть допомогти з виявленням насильницьких ситуацій у сім'ях, бо часто виїжджають додому для огляду й лікування, що дозволяє їм судити про обстановку в сім'ї, про фізичний і психічний стан особи, доглянутість, що може бути цінним джерелом для вжиття профілактичних заходів із метою запобігання насильству.

Надання кваліфікованих консультацій співробітникам інспекцій психологами у справах неповнолітніх та інших служб поліції, представникам громадських організацій щодо шляхів та форм оздоровлення сімейної обстановки підлітків-правопорушників, зміцнення їхніх зв'язків із сім'єю, урегулювання сімейних конфліктів також має вагоме значення як метод виявлення домашнього насилля [4, с. 173].

За допомогою окремих індикаторів поведінки дитини, яка страждає від неадекватних та шкідливих стосунків у родині, також можна виявити випадки насильства в сім'ї. Серед них визначаємо страх, який проявляється в замкненості особи в собі; прояви впертості або мовчазливості в поведінці чи, навпаки, агресивної поведінки; залучення дитини до конфлікту між батьками, унаслідок чого діти наслідують поведінку батьків; захисну поведінку, коли дитина намагається будь-якими способами захистити свою матір від насильства; розчарування внаслідок стресу від домашнього насильства; почуття непотрібності через неувагу батьків до дітей i, як наслідок, депресія та навіть самогубство.

На основі вищевикладеного вбачаємо, що нині необхідно об'єднати зусилля держави зі всіма зацікавленими особами для вирішення проблеми домашнього насильства на якісно новому рівні. Уважаємо, що питання розроблення Концепції протидії домашньому насильству й захисту його жертв давно назріло. Вони повинні охоплювати всі сфери життєдіяльності суспільства й відображати реальні заходи за такими напрямами, як:

1. Законодавчий. Унесення змін до Кримінального кодексу України із запровадженням кримінальної відповідальності за домашнє насильство стало значним кроком до подолання проблеми державного масштабу. Також ухвалено низку нормативно-правових актів, зокрема Закон України «Про запобігання та протидію домашньому насильству», постанови Кабінету Міністрів України щодо порядку формування, ведення та доступу до Єдиного державного реєстру випадків домашнього насильства та насильства за ознакою статі. Проте недоліками в законодавстві вважаємо нера- тифікацію Україною Стамбульської конвенції, що $\epsilon$ важливим міжнародним документом у системі правових актів у цій сфері, наявність прогалин у нормативній базі, які варто усунути.

2. Теоретичний. У рамках цього напряму повинна проводитися постійна дослідницька робота для забезпечення практиків необхідним матеріалом - розроблення методичних посібників і практичних програм. Важливим напрямом розвитку в теорії $\epsilon$ формування методики розслідування домашнього насильства для слідчої діяльності з виявлення, розслідування цих правопорушень і запобігання таким.

3. Практичний. Суть концепції має полягати в розробленні роботи громадськості з потерпілими, у посиленні іï ролі у профілактиці домашнього насильства з позиції зміцнення моральних принципів, у відстеженні міжособистісної взаємодії зловмисника й потенційної жертви.

4. Виховання. Державі варто сконцентрувати сили на створенні більшої кількості державних гуртків, секцій, організацій із проведення дозвілля, щоби молодь розвивала свою особистість у належному моральному та соціальному дусі. Адже, як дітей виховають нині, таким суспільство буде вже через десятиліття.

5. Для профілактики домашнього насильства варто проводити роботу зі злочинцем, який теж підсвідомо страждає та потребує психологічної допомоги. Фахівець повинен допомогти особі розібратись у собі та не шукати «козла відпущення» у родині, зрозуміти та пропрацювати причини накопичення внутрішньої агресії, сформувати навички її подолання.

6. Центри протидії домашньому насильству повинні мати багаторівневий характер - починаючи від місцевого рівня та закінчуючи міжнародним. Реальність така, що в сільській місцевості натепер немає організацій та фахівців із надання послуг потерпілим від насильства в сім'ї. Тому для держави мають набути особливого значення організація та розвиток профілактичних програм для сільської місцевості.

7. Домашнє насильство - не лише особиста справа. Варто здійснювати пропаганду ненасильницьких методів вирішення домашніх конфліктів через засоби інформації та просвітницькі заходи, упровадження у практику засобів масової інформації, консультації та бесіди із проблем правового регулювання сімейних взаємин, збільшення кількості соціальної реклами із проблем сімейної політики, поширення інформації про права членів сім’ї, активно привертати суспільну увагу 
до проблеми сімейного насильства і домашньої жорстокості.

Висновки. Проблема насильства в сім’ї натепер не втрачає актуальності й визнається однією 3 найбільш гострих проблем нашого суспільства. Тому для дієвої боротьби наявності лише кримінального законодавства недостатньо. Необхідний цілий комплекс державних та соціальних заходів, відповідних перетворень у суспільстві, а саме: пропаганда, належне виховання, починаючи із сім’і та закінчуючи державою, залучення засобів масової інформації та комунікації як рушійної сили, робота правоохоронних органів і кооперація дій із медичними й іншими установами з метою виявлення та профілактики домашнього насильства.

\section{Література}

1. Кримінальний кодекс України від 5 квітня 2001 р. № 2341-III / Верховна Рада України. URL: https: / /zakon.rada.gov.ua/laws/show/2341-14\#Text (дата звернення: 20.11.2020).

2. Про запобігання та протидію домашньому насильству : Закон України від 7 грудня 2017 р. № 2229-VIII / Верховна Рада України. URL: https:// zakon.rada.gov.ua/laws/show/2229-19\#Text (дата звернення: 20.11.2020).

3. Гаухман Л.Д. Насилие как средство совершения преступления. Москва : Юрид. лит., 1974. 167 с.

4. Дашиева А.Д. Уголовно-правовая и криминологическая характеристика истязания и его предупреждение : по материалам Восточно-Сибирского региона : дис. ... канд. юрид. наук: 12.00.08. Иркутск, 2009. 240 с.

5. Егорова Н.Ю., Резник С.Д., Бобров В.А. Менеджмент в домашнем хозяйстве. 3-е изд., перераб. и доп. Москва : Инфра-М, 2010. 461 с.

6. Иншаков С.М. Криминология : учебник. Москва : Юриспруденция, 2000. 432 с.

7. Лисюк Ю.В. Протидія насильству в сім’ї. Одеca, 2007. 162 с.

8. Методичні рекомендації щодо надання психосоціальної допомоги особам, постраждалим від ґендерно зумовленого насильства, Департаменту соціального захисту населення Запорізької обласної державної адміністрації. КЗ «Запорізький обласний центр соціально-психологічної допомоги» Запорізької ОДА. Запоріжжя, 2016. С. 34-35. URL: https:// dszn-zoda.gov.ua/sites/default/files/loadfiles/ zvit_2016.doc (дата звернення: 20.11.2020).

9. Насилие и его влияние на здоровье : доклад о ситуации в мире / под ред. Этьенна Г. Круга и др. Пер. с англ. Москва : Весь Мир, 2003. 376 с.

10. Науково-практичний коментар Кримінального кодексу України від 5 квітня 2001 р. / за ред. М.І. Мельника, М.І. Хавронюка. Київ : Канон ; А.С.К., 2001. 1104 c.

11. Оноколов Ю.П. К вопросу об определении понятия «латентные преступления». Уголовно-исполнительная система : право, экономика, управленuе. 2010. № 5. С. 13-16.

12. Орлов А.Б. Психологическое насилие в семье - определение, аспекты, основные направления оказания психологической помощи. Психолог в детском саду. 2000. № № 2-3. С. 182-187.

13. Радзивілова О.В. Психосоціальні особливості жінок, які вчинили насильницькі злочини у стані алкогольного сп'яніння. Психологічний часоnuc. 2017. № 5 (9). С. 139-149.

14. Топчій В.В. Кримінологічна характеристика особи насильницького злочинця. Європейські перспективи. 2015. Вип. 5. С. 85-91. URL: http://nbuv. gov.ua/UJRN/evpe_2015_5_16.

Комісарчук Р. В., кандидат юридичних наук, доцент, доцент кафедри права факультету менеджменту та права Вінницького національного аграрного університету

Островська А. Ю., студентка першого курсу магістратури факультету менеджменту та права

Вінницького національного аграрного університету 